University of Nebraska - Lincoln

DigitalCommons@University of Nebraska - Lincoln

\title{
Influence of Commodity Type, Percentage of Cracked Kernels, and Wheat Class on Population Growth of Stored-Product Psocids (Psocoptera: Liposcelidae)
}

\author{
Christos G. Athanassiou \\ University of Thessaly, athanassiou@agr.uth \\ George P. Opit \\ Oklahoma State University \\ James E. Throne \\ USDA-ARS, Manhattan, KS, james.throne@ars.usda.gov
}

Follow this and additional works at: https://digitalcommons.unl.edu/usdaarsfacpub

Athanassiou, Christos G.; Opit, George P.; and Throne, James E., "Influence of Commodity Type, Percentage of Cracked Kernels, and Wheat Class on Population Growth of Stored-Product Psocids (Psocoptera: Liposcelidae)" (2010). Publications from USDA-ARS / UNL Faculty. 2033.

https://digitalcommons.unl.edu/usdaarsfacpub/2033

This Article is brought to you for free and open access by the U.S. Department of Agriculture: Agricultural Research Service, Lincoln, Nebraska at DigitalCommons@University of Nebraska - Lincoln. It has been accepted for inclusion in Publications from USDA-ARS / UNL Faculty by an authorized administrator of DigitalCommons@University of Nebraska - Lincoln. 


\title{
Influence of Commodity Type, Percentage of Cracked Kernels, and Wheat Class on Population Growth of Stored-Product Psocids (Psocoptera: Liposcelidae)
}

\author{
CHRISTOS G. ATHANASSIOU, ${ }^{1,2}$ GEORGE P. OPIT, ${ }^{3}$ aNd JAMES E. THRONE ${ }^{2}$
}

\begin{abstract}
J. Econ. Entomol. 103(3): 985-990 (2010); DOI: 10.1603/EC09280
ABSTRACT Differences in stored-product psocid progeny production as a function of commodity type, percentage of cracked kernels, and wheat class were examined using laboratory bioassays. Population growth of Liposcelis bostrychophila Badonnel, Liposcelis decolor (Pearman), Liposcelis paeta Pearman, and Liposcelis entomophila (Enderlein) (Psocoptera: Liposcelididae) was highest on sorghum Sorghum bicolor (L.) Moench, followed by wheat, Triticum aestivum L., and rice, Oryza sativa L., whereas progeny production was negligible on wheat germ. In a second experiment that did not include L. entomophila, population growth was examined on wheat containing $0,1,5,10,20,50$, and $100 \%$ cracked kernels. Progeny production did not increase as cracked kernel content increased. Instead, progeny production peaked at $20 \%$ for $L$. bostrychophila adults and nymphs, at $10 \%$ for $L$. decolor, and at $50 \%$ for L. paeta adults; no further increases were noted beyond these levels of cracked wheat content. In a third experiment that did not include L. entomophila, progeny production was examined on eight classes of wheat: hard red winter, hard red spring, soft white winter, soft white spring, soft club, durum, soft red winter, and hard white. Overall, progeny production was higher on durum wheat than on the other classes. The results indicate that there are considerable variations in psocid population growth among the different commodities tested, and this information may be used to predict the degree to which stored commodities are susceptible to psocid infestation.
\end{abstract}

KEY WORDS Liposcelis, varietal resistance, wheat classes

Stored-grain insects are generally polyphagous and can develop on a wide variety of grain-based commodities (Aitken 1975). However, some commodities are less vulnerable to infestation, a characteristic that is affected by several biochemical and physical parameters. These mechanisms may induce the biochemical attributes that can modify behavioral responses of a given insect (antixenosis) or affect its development (antibiosis) (Throne et al. 2000). However, varietal resistance mechanisms are poorly understood. For example, Amos et al. (1986) reported that protein content was negatively associated with progeny production for the rice weevil, Sitophilus oryzae (L.) (Coleoptera: Curculionidae), whereas Khokhar and Gupta (1974) found no correlation between protein content and S. oryzae progeny produc-

Mention of trade names or commercial products in this publication is solely for the purpose of providing specific information and does not imply recommendation or endorsement by the United States Department of Agriculture or the University of Thessaly.

${ }^{1}$ Corresponding author: Laboratory of Entomology and Agricultural Zoology, Department of Agriculture, Plant Production and Rural Environment, University of Thessaly, Phytokou str., N. Ionia Magnissias,38446, Greece (e-mail: athanassiou@agr.uth).

${ }^{2}$ USDA-ARS Grain Marketing and Production Research Center, 1515 College Ave., Manhattan, KS 66502-2736.

${ }^{3}$ Department of Entomology and Plant Pathology, 127 Noble Research Center, Oklahoma State University, Stillwater, OK 74078-3033. tion. Similarly, kernel size and hardness play an important role in population growth of the lesser grain borer, Rhyzopertha dominica (F.) (Coleoptera: Bostrichidae), according to Amos et al. (1986), but they are not important according to other studies (McGaughey et al. 1990, Toews et al. 2000). Nevertheless, knowledge of the susceptibility level of commodities, e.g., wheat, Triticum aestivum L., varieties, can be used to predict dynamics of insect population growth in a given time period (Throne 1989).

Psocids are newly emerged pests of stored grains and related amylaceous commodities. They cause serious quantitative losses and qualitative degradation, and they are often found in extremely high numbers, particularly in grain bulks (Opit et al. 2009a,b). Apart from abiotic factors such as temperature and relative humidity, the type of commodity is determinative for psocid development (Rees and Walker 1990; Nayak and Collins 2001; Opit and Throne 2008a,b). However, most of the studies available on the influence of diet are focused on the effect of diet to enhance the laboratory rearing of psocids, but there is still inadequate information on the effect of types of grain, or grain characteristics, on progeny production. In the current study, we examined the effect of 1) commodity, particularly grain type; 2) percentage of cracked kernels; and 3) wheat class on the population growth of some 
of the most commonly found stored-product psocid pest species.

\section{Materials and Methods}

Psocid Species. Four psocid species were used in the tests: Liposcelis bostrychophila Badonnel, Liposcelis decolor (Pearman), Liposcelis entomophila (Enderlein), and Liposcelis paeta Pearman (Psocoptera: Liposcelididae), and voucher specimens were deposited in the Kansas State University Museum of Entomological and Prairie Arthropod Research (Manhattan, KS) under lots 182, 202, 205, and 207, respectively. All species were reared on a mixture of $97 \%$ cracked wheat kernels, $2 \%$ crisped rice breakfast cereals (Kellogg Company, Battle Creek, MI), and 1\% brewer's yeast at $30^{\circ} \mathrm{C}$ and $70 \% \mathrm{RH}$, as suggested by Opit and Throne (2008b). Less than 4-wk-old adult females were used in the tests. The adults were handled according to the procedure described by Opit and Throne (2008b).

Bioassays. Effect of Grain Commodities. Untreated, clean, and infestation-free wheat (a mixture of the variety Fuller and Santa Fe); rice, Oryza sativa L. (variety Francis); oat, Avena sativa L. (variety Paul); sorghum Sorghum bicolor (L.) Moench (hybrid F1000); and maize, Zea mays L. (hybrid Golden Harvest H-8713), as well as wheat germ (Bob's Red Mill Natural Food, Milwaukie, OR) were used in the tests. Moisture content of the commodities was adjusted to $13.5 \%$ before the beginning of the experiments. To preclude incipient insect and mite infestations (also in the other two series of experiments), the commodities were kept in the refrigerator until the beginning of the experiments. Six hundred grams of each commodity was placed in 0.473-liter glass jars, and six 10-g samples were taken from each jar and placed in plastic cylindrical vials $(3 \mathrm{~cm}$ in diameter, $8 \mathrm{~cm}$ in height). Hence, there were six replicates for each commodity. Then, five adult females of $L$. bostrychophila were placed in each vial. The same procedure was followed for the other species by taking new samples from the jars. The vials had a plastic lid with a hole in the center covered with a U.S. \#40 fine mesh screen (0.42-mm openings). The top one quarter of the inside of each vial was covered by Fluon (Northern Products, Woonsocket, RI) to prevent psocids from escaping. All vials were then placed randomly in black plastic boxes with a saturated sodium chloride solution to maintain $75 \%$ RH (Greenspan 1977). The boxes were then placed in incubators set at $30^{\circ} \mathrm{C}$ and $75 \% \mathrm{RH}$. The vials were opened after $35 \mathrm{~d}$, and the numbers of live adults and nymphs were recorded.

Effect of Cracked Wheat Kernels. Only L. bostrychophila, L. decolor, and L. paeta were used in this experiment. A mixture of the wheat varieties Fuller and Santa Fe, adjusted to $13.5 \%$, was used. Seven jars containing $0,1,5,10,20,50$, and $100 \%$ cracked kernels were prepared. The wheat was cracked as suggested by Opit and Throne (2008a). Materials and methods were similar to those in the previous experiment; each treatment had six vials (six replicates).

Effect of Wheat Class. Only L. bostrychophila, L. decolor, and L. paeta were used in this experiment. Eight different classes of wheat (adjusted to 13.5\%) were evaluated: 1) hard red winter wheat (variety Newton);2) hard red spring wheat (variety Kulm); 3) soft white winter wheat (variety Madsen); 4) soft white spring wheat (variety Alpowa); 5) soft white winter club wheat (variety Tres); 6) durum wheat (unknown variety, originated from El Toro, CA); 7) soft red winter wheat (variety Caldwell-Ohio); and 8) hard white wheat (variety Blanca Grande). Sample arrangement, conditions, and progeny measurement were as described above.

Data Analysis. Data were analyzed separately for each experiment, species, and life stage (adults or nymphs) by using a one-way analysis of variance (ANOVA) (Sall et al. 2001). Before the analysis, all data sets were submitted separately to Levene test, to examine the homogeneity of variances. When variances were not equal, the data were transformed to arc-tangent scale (indicated in the tables). Means were separated by using the Tukey-Kramer honestly significant difference (HSD) test at 0.05 .

\section{Results}

Effect of Grain Commodities. The highest number of progeny was recorded for L. entomophila and the least for $L$. decolor (Table 1). The greatest numbers of $L$. bostrychophila adult progeny were found on wheat and sorghum, and no adult progeny were found on wheat germ. The only commodity where $>70$ L. bostrychophila nymphs per vial were found was on sorghum; progeny nymphs did not exceed 31 individuals per vial in the other commodities, and no nymphs were found on wheat germ. Significantly more L. decolor adult progeny were found on oat and sorghum than on the other four commodities, although adult progeny production never exceeded 20 individuals. No significant differences were noted among commodities for $L$. decolor nymphs. More $L$. paeta adults and nymphs were found on wheat, rice, and sorghum, although adult progeny production never exceeded 32 individuals. More than $100 \mathrm{~L}$. entomophila adults were recorded on wheat and sorghum, and the number of adults on wheat germ was negligible. The highest number of $L$. entomophila nymphs was recorded on sorghum, and no nymphs were found on wheat germ.

Effect of Cracked Wheat. Overall, more progeny were found for L. bostrychophila than for the other two species tested (Table 2). For this species, significant differences in the numbers of adults were noted only between whole wheat and wheat containing $20 \%$ cracked kernels. Similarly, significantly more L. bostrychophila nymphs were recorded in vials containing $20 \%$ cracked wheat than in vials with other percentages of cracked wheat. The increase in $L$. decolor adult progeny with increase in cracked wheat content was not pronounced. However, significantly 
Table 1. Progeny production, expressed as number of adults or nymphs/vial (mean \pm SE), of four Liposcelis psocid species on different commodities (within each column, means followed by the same letter are not significantly different; HSD test at 0.05 , in all cases df = $\mathbf{5 , 3 0})^{\boldsymbol{a}}$

\begin{tabular}{|c|c|c|c|c|c|c|c|c|}
\hline \multirow{2}{*}{ Commodity } & \multicolumn{2}{|c|}{ L. bostrychophila } & \multicolumn{2}{|c|}{ L. decolor } & \multicolumn{2}{|c|}{ L. paeta } & \multicolumn{2}{|c|}{ L. entomophila } \\
\hline & Adults & Nymphs & Adults & Nymphs & Adults & Nymphs & Adults & Nymphs \\
\hline Wheat & $55.8 \pm 7.1 \mathrm{a}$ & $25.7 \pm 3.1 b$ & $8.7 \pm 2.6 b$ & $13.3 \pm 4.4 \mathrm{a}$ & $31.8 \pm 7.4 \mathrm{a}$ & $20.0 \pm 7.1 \mathrm{a}$ & $106.2 \pm 9.2 \mathrm{a}$ & $76.0 \pm 13.1 b$ \\
\hline Rice & $40.7 \pm 8.4 \mathrm{ab}$ & $30.7 \pm 13.2 b$ & $7.8 \pm 2.9 b$ & $8.0 \pm 2.3 \mathrm{a}$ & $27.8 \pm 6.9 \mathrm{ab}$ & $20.3 \pm 5.6 \mathrm{a}$ & $93.7 \pm 10.5 \mathrm{ab}$ & $52.2 \pm 10.6 \mathrm{~b}$ \\
\hline Oat & $24.8 \pm 9.0 \mathrm{bc}$ & $10.0 \pm 2.6 b$ & $20.7 \pm 3.3 a$ & $14.5 \pm 4.2 \mathrm{a}$ & $2.7 \pm 2.1 \mathrm{c}$ & $2.7 \pm 2.7 \mathrm{~b}$ & $60.5 \pm 15.7 \mathrm{~b}$ & $48.0 \pm 10.7 \mathrm{~b}$ \\
\hline Sorghum & $62.5 \pm 5.6 \mathrm{a}$ & $70.5 \pm 13.8 \mathrm{a}$ & $20.2 \pm 2.8 \mathrm{a}$ & $17.5 \pm 3.3 \mathrm{a}$ & $19.5 \pm 2.4 \mathrm{ab}$ & $19.3 \pm 4.8 \mathrm{a}$ & $127.0 \pm 11.0 \mathrm{a}$ & $118.1 \pm 10.5 \mathrm{a}$ \\
\hline Maize & $12.8 \pm 3.5 \mathrm{c}$ & $13.2 \pm 6.1 b$ & $6.2 \pm 1.3 \mathrm{~b}$ & $9.5 \pm 3.0 \mathrm{a}$ & $9.8 \pm 1.8 \mathrm{bc}$ & $5.8 \pm 1.8 \mathrm{~b}$ & $29.7 \pm 6.8 c$ & $27.3 \pm 7.6 c$ \\
\hline Wheat germ & $0.0 \pm 0.0 \mathrm{~d}$ & $0.0 \pm 0.0 \mathrm{c}$ & $5.2 \pm 0.7 \mathrm{~b}$ & $4.0 \pm 0.9 \mathrm{a}$ & $6.2 \pm 0.9 c$ & $3.7 \pm 0.8 b$ & $0.2 \pm 0.2 \mathrm{~d}$ & $0.0 \pm 0.0 \mathrm{~d}$ \\
\hline$F$ & 14.7 & 11.4 & 3.8 & 0.7 & 7.3 & 4.0 & 23.2 & 17.8 \\
\hline$P$ & $<0.01$ & $<0.01$ & $<0.01$ & 0.58 & $<0.01$ & $<0.01$ & $<0.01$ & $<0.01$ \\
\hline
\end{tabular}

${ }^{a}$ Data were arc-tangent transformed only for $L$. decolor adults and nymphs (Levene's test for $L$. bostrychophila, adults $F=3.7, P<0.01$ and nymphs $F=6.5, P<0.01$; for $L$. decolor, adults $F=1.9, P=0.12$ and nymphs $F=1.8, P=0.13$; for $L$. paeta, adults $F=7.1, P<0.01$ and nymphs $F=4.7, P<0.01$; and for $L$. entomophila, adults $F=4.0, P<0.1$ and nymphs $F=4.2, P<0.01$. In all cases, df $=5.30$ (untransformed values are presented in the table).

more adults and nymphs were recorded in vials containing $10 \%$ or more cracked wheat than in vials containing whole kernels. No significant differences were noted among treatments for $L$. decolor adults or nymphs.

Effect of Wheat Class. Significantly more $L$. bostrychophila adults were recorded on durum wheat than on the other wheat classes, whereas the lowest number of adults was found on hard red winter and soft white spring wheat (Table 3). The highest numbers of $L$. bostrychophila nymphs were found on durum wheat and soft white club. Significantly more $L$. decolor adults and nymphs were found on durum wheat than on other wheat classes, and the lowest number of progeny was found on hard red winter wheat. Similarly, the number of $L$. paet $a$ adult progeny was much higher on durum wheat than on the other classes of wheat. However, no significant differences were recorded among wheat classes for L. paeta nymphs.

\section{Discussion}

Our study demonstrates that psocids can develop high population densities, even during a short 35-d interval, in a large variety of amylaceous products.
This observation is indicative of their wide food preferences. Numbers of adult psocids increased by as much as 25-fold from an initial population of five females in some of the commodities used in our study. However, population growth was influenced by the type of commodity and the psocid species. Based on our results, psocids can be considered capable of surviving and reproducing on whole kernels, for all the grain commodities examined. This characteristic is particularly important, given that insect species that are able to feed on sound raw grain kernels pose a greater economic risk in grain bulks compared with species that require the presence of cracked kernels. Other studies have also shown that psocids can damage sound kernels (Rees and Walker 1990, Kurová 1999). According to Kučerová (2002), weight loss in stored grain due to psocid infestations can exceed $10 \%$. Opit and Throne (2008b) noted that L. entomophila and Lepinotus reticulatus Enderlein (Psocoptera: Trogiidae) could develop on several grain commodities, but population growth varied among commodities. They noted that maize was less suitable than wheat, rice, barley (Hordeum vulgare L.), sorghum, or oat for L. reticulatus, whereas wheat, barley, and sorghum were more suitable than oat, rice, and maize for $L$. entomophila. Our results are partially in agreement

Table 2. Progeny production, expressed as number of adults or nymphs/vial (mean $\pm \mathrm{SE}$ ), of three Liposcelis psocid species on wheat containing different percentages of cracked kernels (within each column, means followed by the same letter are not significantly different; HSD test at 0.05 , in all cases $\mathrm{df}=6,35)^{a}$

\begin{tabular}{|c|c|c|c|c|c|c|}
\hline \multirow{2}{*}{$\%$ cracked } & \multicolumn{2}{|c|}{ L. bostrychophila } & \multicolumn{2}{|c|}{ L. decolor } & \multicolumn{2}{|c|}{ L. paeta } \\
\hline & Adults & Nymphs & Adults & Nymphs & Adults & Nymphs \\
\hline 0 & $67.3 \pm 14.7 \mathrm{~b}$ & $85.8 \pm 15.1 b$ & $15.7 \pm 3.9 \mathrm{~b}$ & $8.3 \pm 1.8 \mathrm{c}$ & $26.7 \pm 3.7 \mathrm{a}$ & $31.8 \pm 4.5 \mathrm{a}$ \\
\hline 1 & $94.6 \pm 10.2 \mathrm{ab}$ & $64.7 \pm 6.4 \mathrm{~b}$ & $21.2 \pm 5.8 \mathrm{ab}$ & $14.0 \pm 4.5 \mathrm{bc}$ & $32.5 \pm 7.2 \mathrm{a}$ & $71.6 \pm 38.1 \mathrm{a}$ \\
\hline 5 & $94.8 \pm 5.7 \mathrm{ab}$ & $115.7 \pm 25.1 b$ & $27.3 \pm 3.4 \mathrm{ab}$ & $17.5 \pm 5.6 \mathrm{bc}$ & $27.2 \pm 4.3 \mathrm{a}$ & $28.6 \pm 5.3 \mathrm{a}$ \\
\hline 10 & $86.0 \pm 8.5 \mathrm{ab}$ & $124.0 \pm 18.2 b$ & $35.0 \pm 5.2 \mathrm{a}$ & $33.0 \pm 10.1 \mathrm{ab}$ & $36.7 \pm 5.9 \mathrm{a}$ & $56.1 \pm 8.9 \mathrm{a}$ \\
\hline 20 & $122.5 \pm 9.6 \mathrm{a}$ & $280.8 \pm 57.5 \mathrm{a}$ & $39.3 \pm 7.2 \mathrm{a}$ & $48.5 \pm 15.6 \mathrm{a}$ & $30.8 \pm 4.6 \mathrm{a}$ & $59.8 \pm 10.9 \mathrm{a}$ \\
\hline 50 & $71.2 \pm 12.8 \mathrm{ab}$ & $129.2 \pm 17.4 \mathrm{~b}$ & $43.5 \pm 7.7 \mathrm{a}$ & $54.0 \pm 13.7 \mathrm{a}$ & $61.2 \pm 12.4 \mathrm{a}$ & $55.8 \pm 11.9 \mathrm{a}$ \\
\hline 100 & $111.7 \pm 12.1 \mathrm{ab}$ & $100.2 \pm 11.1 \mathrm{~b}$ & $35.2 \pm 6.6 \mathrm{a}$ & $58.3 \pm 14.6 \mathrm{a}$ & $24.8 \pm 5.9 \mathrm{a}$ & $50.8 \pm 13.9 \mathrm{a}$ \\
\hline$F$ & 2.8 & 7.1 & 3.0 & 3.6 & 1.3 & 0.8 \\
\hline$P$ & 0.02 & $<0.01$ & 0.01 & $<0.01$ & 0.29 & 0.57 \\
\hline
\end{tabular}

${ }^{a}$ Data were arc-tangent transformed only for L. bostrychophila adults, L. decolor adults, and L. paeta adults (Levene's test for L. bostrychophila, adults $F=0.9, P=0.49$ and nymphs $F=3.4, P<0.01$; for $L$. decolor, adults $F=0.9, P=0.53$ and nymphs $F=2.4, P=0.04$; for $L$. paeta, adults $F=1.7, P=0.15$ and nymphs $F=2.9, P=0.02$ ). In all cases, $\mathrm{df}=6.35$ (untransformed values are presented in the table). 
Table 3. Progeny production, expressed as number of adults or nymphs per vial (mean \pm SE), of three psocid species on different classes of wheat (within each column, means followed by the same letter are not significantly different; HSD test at 0.05 , in all cases df = $7,40)^{a}$

\begin{tabular}{|c|c|c|c|c|c|c|}
\hline \multirow{2}{*}{ Class of wheat } & \multicolumn{2}{|c|}{ L. bostrychophila } & \multicolumn{2}{|c|}{ L. decolor } & \multicolumn{2}{|c|}{ L. paeta } \\
\hline & Adults & Nymphs & Adults & Nymphs & Adults & Nymphs \\
\hline Hard red winter & $21.0 \pm 4.9 \mathrm{~d}$ & $28.5 \pm 6.2 \mathrm{c}$ & $4.5 \pm 2.0 \mathrm{~d}$ & $7.2 \pm 2.9 \mathrm{~d}$ & $41.3 \pm 7.1 \mathrm{~d}$ & $65.8 \pm 5.7 \mathrm{a}$ \\
\hline Hard red spring & $58.2 \pm 14.1 b$ & $67.3 \pm 15.8 \mathrm{~b}$ & $8.0 \pm 2.4 \mathrm{~cd}$ & $9.2 \pm 3.4 \mathrm{~cd}$ & $63.0 \pm 7.9 \mathrm{~cd}$ & $48.3 \pm 6.2 \mathrm{a}$ \\
\hline Soft white winter & $61.7 \pm 11.4 \mathrm{~b}$ & $44.5 \pm 6.2 \mathrm{bc}$ & $23.7 \pm 3.8 b$ & $18.0 \pm 3.2 \mathrm{bc}$ & $63.0 \pm 11.5 \mathrm{~cd}$ & $97.3 \pm 29.9 a$ \\
\hline Soft white spring & $28.2 \pm 3.6 \mathrm{~cd}$ & $44.3 \pm 3.3 \mathrm{bc}$ & $26.8 \pm 5.2 \mathrm{~b}$ & $26.3 \pm 5.1 b$ & $71.0 \pm 8.9 \mathrm{bc}$ & $73.2 \pm 7.3 \mathrm{a}$ \\
\hline Soft white club & $42.5 \pm 8.2 \mathrm{bc}$ & $93.2 \pm 2.6 \mathrm{a}$ & $15.3 \pm 3.4 \mathrm{c}$ & $13.2 \pm 3.1 \mathrm{~cd}$ & $77.5 \pm 9.4 b$ & $79.5 \pm 10.9 a$ \\
\hline Durum & $100.5 \pm 8.6 \mathrm{a}$ & $99.7 \pm 7.1 \mathrm{a}$ & $94.7 \pm 5.7 \mathrm{a}$ & $51.6 \pm 4.6 \mathrm{a}$ & $132.5 \pm 18.3 \mathrm{a}$ & $80.0 \pm 9.1 \mathrm{a}$ \\
\hline Soft red winter & $40.3 \pm 5.0 \mathrm{bc}$ & $55.3 \pm 5.5 b$ & $16.7 \pm 4.9 c$ & $10.8 \pm 4.3 \mathrm{~cd}$ & $54.8 \pm 4.5 \mathrm{~cd}$ & $59.0 \pm 6.9 \mathrm{a}$ \\
\hline Hard white & $54.3 \pm 9.6 \mathrm{~b}$ & $57.7 \pm 8.7 \mathrm{~b}$ & $14.5 \pm 3.1 \mathrm{c}$ & $9.3 \pm 2.1 \mathrm{~cd}$ & $50.6 \pm 8.6 \mathrm{~cd}$ & $38.3 \pm 6.9 \mathrm{a}$ \\
\hline F & 6.8 & 9.6 & 2.4 & 9.6 & 3.4 & 2.2 \\
\hline$P$ & $<0.01$ & $<0.01$ & 0.03 & $<0.01$ & 0.01 & 0.06 \\
\hline
\end{tabular}

${ }^{a}$ Data were arc-tangent transformed only for L. bostrychophila adults, L. decolor adults, and nymphs, and L. paeta adults (Levene's test for $L$. bostrychophila, adults $F=1.6, P=0.16$ and nymphs $F=2.9, P<0.01$; for $L$. decolor, adults $F=1.5, P=0.17$ and nymphs $F=1.3, P=0.26$; for $L$. paeta, adults $F=1.7, P=0.13$ and nymphs $F=3.9, P<0.01$ ). In all cases, $\mathrm{df}=7,40$ (untransformed values are presented in the table).

with those of Opit and Throne (2008b), given that $L$. entomophila population growth was found to be higher on wheat and sorghum, than on maize and oat. Taking into account the combined progeny data, although each species had different population growth trends, sorghum was suitable for all species. As expected, psocid development was extremely poor on wheat germ. This is because the germ of cereals are high in protein, lipid, mineral (ash), and vitamins but are devoid of starch (Hoseney and Faubion 1992), which is vital for energy provision. Addition of wheat germ to psocid diets made of cracked grain alone may boost population growth by providing additional high levels of nutrients (G.P.O., unpublished data).

The presence of cracked wheat resulted in increased progeny production in the species tested. The effect of cracked kernels was more pronounced for $L$. bostrychophila. However, the gradual increase in cracked wheat content was not linearly correlated with progeny increase, suggesting that there is a critical cracked wheat content that enhances population growth, and that higher cracked wheat contents may have an adverse effect on survival or progeny production. Based on the overall progeny data, $20 \%$ cracked wheat content can be considered as "critical" given that further increase negatively affects population growth. For laboratory rearing of $L$. bostrychophila, $L$. paeta, and L. entomophila, Nayak and Collins (2001) proposed a diet based on a mixture of whole wheat, kibbled (cracked) wheat, and wheat flour. For L. entomophila, Opit and Throne (2008b) noted that population increase was higher on cracked wheat than on a diet based on $97 \%$ cracked wheat, $2 \%$ rice krispies, and $1 \%$ brewer's yeast (wt:wt). In that study, the authors reported that there is an inverse relationship between psocid population growth and diet compactness, which may explain the lack of a linear correlation between psocid population growth and the percentage of cracked wheat present above a certain cracked wheat percentage. Diet compactness would be expected to be directly proportional to the percentage of cracked kernels present in a given diet.
Our results suggest that, for $L$. decolor, the increase in cracked wheat content is positively associated with increase in progeny production, especially for progeny nymphs. For example, the population (adults + nymphs) increased $\approx 18$-fold from an initial population of five females in vials containing $100 \%$ cracked wheat. Generally, population growth was poor on a diet containing no cracked wheat. Population growth of L. paeta was increased at cracked wheat content of $50 \%$ and then declined at $100 \%$ cracked wheat content. Our results show that there were different population growth trends between adults and nymphs for all three psocid species. The population of L. paeta adult progeny was higher in some cracked wheat and wheat class categories, whereas no such differences were noted for nymphs. This observation may indicate that diet differences may reflect differences in developmental parameters, which indirectly enhance a faster egg-toadult development. Opit and Throne (2008b) noted that sex ratio differed among diets and that the proportion of females was higher in diets that were less suitable for development. In our study, the diets that were more suitable resulted in higher numbers for both adults and nymphs. The influence of diet on developmental parameters has been recorded for other stored-product insects (Meagher et al. 1982, Throne and Culik 1989, Throne et al. 2000, Toews et al. 2000, Chanbang et al. 2008). For example, Meagher et al. (1982) found that population growth of the maize weevil, Sitophilus zeamais Motschulsky (Coleoptera: Curculionidae), was similar on whole millet and millet containing $10 \%$ cracked kernels, whereas a diet of $100 \%$ cracked kernels was more suitable for the red flour beetle, Tribolium castaneum (Herbst) (Coleoptera: Tenebrionidae). Similarly, Throne and Culik (1989) noted that development of the rusty grain beetle, Cryptolestes ferrugineus (Stephens) (Coleoptera: Laemophloeidae), was faster on cracked than on whole maize.

Classes of wheat vary considerably in their chemical composition, and also in other nonchemical characteristics such as kernel hardness, density, and size 
(Pomeranz et al. 1988, McGaughey et al. 1990). The class of wheat is an important parameter, often determinative for both insect development and insecticidal efficacy. For example, McGaughey et al. (1990) compared the susceptibility of five classes of wheat to infestation by S. oryzae and R. dominica and found that kernel size and density did not correlate well with the population growth of either species. However, kernel hardness was an important criterion for S. oryzae but not for R. dominica (McGaughey et al. 1990). In light of our findings, durum wheat was overall more suitable than the other wheat classes for the population growth of L. bostrychophila, L. decolor, and L. paeta. Generally, durum wheat has higher kernel hardness, kernel size, and protein content compared with some of the other wheat classes (McGaughey et al. 1990, Toews et al. 2000). However, for $R$. dominica, Toews et al. (2000) found that there is no correlation between progeny production and protein content or kernel hardness, but they found that kernel size was negatively correlated with progeny production. In our study, similar numbers of L. bostrychophila nymphs were produced on soft white club and durum, but adult numbers in durum were significantly higher than those in other wheat classes. Moreover, wheat class had no effect on L. paeta nymph population. As noted above, certain physical and chemical characteristics may accelerate development to the adult stage. Taking into consideration the above-mentioned observations, the rearing medium on which the parental individuals had been reared before their introduction to the different diets may influence their longevity and fecundity parameters in an equally important degree with the influence of a given diet to egg hatching and immature development. However, it should be noted that these present data are indicative only in the case of the varieties tested and should not be generalized among wider groups of commodities, such as classes of wheat or grain species.

Varietal resistance is one of the basic components that should be seriously taken into account when a stored-product integrated pest management-based strategy is planned (Throne et al. 2000). The results of the current study could be practically used in this effort, because the grain type, and some of its characteristics, such as the proportion of cracked kernels, can be used as indicators to predict the degree to which certain commodity is susceptible to psocid infestation. Additional studies are needed to determine the potential mechanisms that affect this susceptibility and their interactions with psocid biological parameters.

\section{Acknowledgments}

We thank Ann Redmon and Ngunza Kisangani for technical assistance.

\section{References Cited}

Aitken, A. D. 1975. Insect travelers, I: Coleoptera. Tech. Bull. 31. HMSO, London, United Kingdom.
Amos, T. G., R. L. Semple, and P. Williams. 1986. Multiplication of some stored grain insects on varieties of wheat. Gen. Appl. Entomol. 18: 48-52.

Chanbang, Y., F. H. Arthur, G. E. Wilde, and J. E. Throne. 2008. Hull characteristics as related to susceptibility of different varieties of rough rice to Rhyzopertha dominica (F.) (Coleoptera: Bostrichidae). J. Stored Prod. Res. 44: 205-212.

Greenspan, L. 1977. Humidity fixed points of binary saturated aqueous solutions. J. Res. Natl. Bur. Stand. A. 81: $89-96$.

Hoseney, R. C., and J. M. Faubion. 1992. Physical properties of cereal grains, pp. 1-38. In D. B. Sauer (ed.) Storage of cereal grains and their products. American Association of Cereal Chemists, Inc. St. Paul, MN.

Khokhar, D. S., and D. S. Gupta. 1974. Relative resistance of some varieties of wheat to Sitophilus oryzae (L.) and Rhyzopertha dominica (F.) at different temperatures. Bull. Grain Technol. 12: 117-123.

Kučerová, Z. 2002. Weight losses of wheat grains caused by psocid infestation. Plant Prot. Sci 38: 103-107.

Kurová, Z. 1999. Vulnerability of wheat varieties to storedproduct psocids, pp. 1251-1254. In Z. Jin, Q. Liang, Y. Liang, X. Tan, and L. Guan (eds.), Proceedings of the 7th International Working Conference on Stored-Product Protection, 14-19 October 1998, Beijing, China. Sichuan Publishing House of Science and Technology, Chengdu, China.

McGaughey, W. H., R. D. Speirs, and C. R. Martin. 1990. Susceptibility of classes of wheat grown in the United States to stored-grain insects. J. Econ. Entomol. 83: 11221127.

Meagher, R. L. Jr., C. Reed, and R. B. Mills. 1982. Development of Sitophilus zeamais and Tribolium castaneum on whole, cracked and ground pearl millet. J. Kansas Entomol. Soc. 55: 91-94.

Nayak, M. K., and P. J. Collins. 2001. An improved method for mass rearing three liposcelid psocids (Psocoptera: Liposcelidae) infesting stored commodities. J. Stored Prod. Res. 37: 323-328.

Opit, G. P., and J. E. Throne. 2008a. Population growth and development of the psocid Lepinotus reticulatus at constant temperatures and relative humidities. J. Econ. Entomol. 101: 605-615.

Opit, G. P., and J. E. Throne. 2008b. Effects of diet on population growth of psocids Lepinotus reticulatus and Liposcelis entomophila. J. Econ. Entomol. 101: 616-622.

Opit, G. P., J. E. Throne, and P. W. Flinn. 2009a. Temporospatial distribution of the psocids Liposcelis entomophila and L. decolor (Psocoptera: Liposcelididae) in steel bins containing wheat. J. Econ. Entomol. 102: 13691376.

Opit, G. P., J. E. Throne, and P. W. Flinn. 2009b. Evaluation of five sampling methods for the psocids Liposcelis entomophila and L. decolor (Psocoptera: Liposcelididae) in steel bins containing wheat. J. Econ. Entomol. 102: 13771382 .

Pomeranz, Y., Z. Czuchajowska, M. D. Shogren, G. L. Rubenthalar, L. C. Bolte, H. C. Jeffers, and P. J. Mattern. 1988. Hardness and functional (bread and cookie-making) properties of U. S. wheat. Cereal Foods World 33: 297-304.

Rees, D. P., and A. J. Walker. 1990. The effect of temperature and relative humidity on population growth of three Liposcelis species (Psocoptera: Liposcelidae) infesting stored products in tropical countries. Bull. Entomol. Res. 80: 353-358. 
Sall, J., A. Lehman, and L. Creighton. 2001. JMP Start Statistics. A guide to statistics and data analysis using JMP and JMP IN software. Duxbury Press, Belmont, CA.

Throne, J. E. 1989. Effects of noncatastrophic control technologies that alter life history parameters on insect population growth: a simulation study. Environ. Entomol. 18: 1050-1055.

Throne, J. E., and M. P. Culik. 1989. Progeny production and duration of development of rusty grain beetles, Cryptolestes ferrugineus (Stephens) (Coleoptera: Cucujidae), on cracked and whole corn. J. Entomol. Sci. 24: 150-155.
Throne, J. E., J. E. Baker, F. J. Messina, K. J. Kramer, and J. A. Howard. 2000. Varietal resistance, pp. 166-192. In Bh. Subramanyam and D. W. Hagstrum (eds.), Alternatives to pesticides in stored-product IPM. Kluwer Academic Publishers, Boston, MA.

Toews, M. D., G. W. Cuperus, and T. W. Phillips. 2000. Susceptibility of eight US wheat cultivars to infestation by Rhyzopertha dominica (Coleoptera: Bostrichidae). Environ. Entomol. 29: 250-255.

Received 16 August 2009; accepted 23 December 2009. 